\title{
COP26: more challenges than achievements
}

\author{
Naveen Kumar Arora ${ }^{1}$ - Isha Mishra ${ }^{2}$ \\ Published online: 8 December 2021 \\ (c) Society for Environmental Sustainability 2021
}

"Conference of the Parties" or COPs is a global climate summit which was started by United Nations (UN) to bring all the countries of the world together in order to escalate goals of Paris Agreement (2015) and the UN Framework Convention on Climate Change (UNFCCC) (a treaty that came into force in 1994) (https://ukcop26.org/wp-content/uploads/ 2021/07/COP26-Explained.pdf). This year (2021) was the 26th annual summit of COPs, hence given the name COP26 and was held at Glasgow, United Kingdom (UK) in partnership with Italy. COP26 is one of the biggest and most significant summits on climate change since the Paris Agreement in 2015) (https://www.nationalgrid.com/responsibility/ environment/cop26). Paris Agreement was an international treaty on climate change and was taken up by 196 Parties at COP21 where countries were determined to put forward the plans on how to reduce their emissions, known as Nationally Determined Contributions, or NDCs. The main target was to restrict global warming to below $2{ }^{\circ} \mathrm{C}$, preferably 1.5 ${ }^{\circ} \mathrm{C}$ when compared to pre-industrial era (https://unfccc.int/ process-and-meetings/the-paris-agreement/the-paris-agree ment). In COP26 nearly 200 countries participated to adopt the 'Climate Pact', which is directly related to Paris Agreement rulebook and is a way forward to keep the aims of the treaty alive in order to spike the decarbonisation of the global economy (https://ec.europa.eu/commission/presscorner/detail/en/ip_21_6021). The Glasgow meeting made few progresses, such as cutting down on emissions, declaration on zero-emission vehicles to promote greener transport and acknowledging deforestation, but looking at the outcome of the conference, the evaluation reveals that the targets have not been achieved and overall the roadmap is not very clear. The signatories do not seem to be unified against the

Naveen Kumar Arora

nkarora.bbau@gmail.com

1 Department of Environmental Science, School of Earth and Environment Sciences, Babasaheb Bhimrao Ambedkar University, Vidya Vihar, Raebareli Road, Lucknow, India

2 Department of Microbiology, Babasaheb Bhimrao Ambedkar University, Vidya Vihar, Raebareli Road, Lucknow, India environmental menace, just like the nations have failed to show united front to COVID-19.

There are four major goals that have been set up to achieve at COP26. First is to secure global net zero carbon by mid-century, keeping $1.5{ }^{\circ} \mathrm{C}$ within reach (https:// ukcop26.org/cop26-goals/). To keep the first target within reach global emissions must be reduced by $45 \%$ by 2030 in comparison to levels of 2010 (https://www.nature.com/ articles/d41586-021-03431-4). Climate change is no more a low-level issue but has become a life threatening global emergency. According to a study by Climate Action Tracker, even if the pledges announced at the COP26 meeting are enforced, still temperatures are predicted to rise by $2.4{ }^{\circ} \mathrm{C}$ up to 2100 . This is much above the target of $1.5^{\circ} \mathrm{C}$ accepted at the Paris Agreement and the effects of this are likely to be catastrophic in future (https://www.nature.com/articles/ d41586-021-03433-2). In fact, in the latest report of Intergovernmental Panel on Climate Change (IPCC), it has been revealed that the planet is going to witness the limit of 1.5 ${ }^{\circ} \mathrm{C}$ in early 2030s itself, triggering irreversible changes in our environment (such as flooding, drought, bushfires, and destruction of species) and called it 'code red for humanity' (https://www.ipcc.ch/sr15/). According to a global climate report published by World Meteorological Organisation (WMO) (2021), despite the fact that the world was stalled due to pandemic caused by novel corona virus (COVID-19) for last 2 years, yet the global mean temperature in 2021 i.e. between January and September was $1.08 \pm 0.13{ }^{\circ} \mathrm{C}$ more than the 1850-1900 (pre-industrial era). The report also suggests that as a result of rising temperatures, global sea levels have also risen by $4.4 \mathrm{~mm} /$ year between 2013 and 2021 (State of the Global Climate 2021 https://library.wmo.int/ doc_num.php?explnum_id=10859). Oceans are known to produce $50 \%$ of atmospheric oxygen, absorb $25 \%$ of anthropogenic carbon dioxide $\left(\mathrm{CO}_{2}\right)$ emissions and trap $90 \%$ of excess heat in the climate system. To highlight the important connect between oceans and climate change, European Union (EU) called for 'EU Ocean Day' at COP26. However, acidification of oceans due to unprecedented rate of global warming and overexploitation of its resources remains to be 
marginalised at climate change negotiations thus hampering its sustainability (https://theconversation.com/cop26-failedto-address-ocean-acidification-but-the-law-of-the-seasmeans-states-must-protect-the-worlds-oceans-171949). Data reveals that $14 \%$ of coral species have already vanished; Arctic has lost ice sheets about six times the size of Germany in last 40 years and marine species are disappearing at double the rate than on land (https://ec.europa.eu/oceans-and-fishe ries/news/cop-26-eu-ocean-day-highlights-role-oceans-tackl ing-climate-change-2021-10-29_en).

To further translate the targets of COP26 into actions, one of the objective was to phase out coal and all nations to stop financing or giving subsidies to new coal-fired power plants. A study published in Nature by Welsby et al. (2021) suggests that in order to limit the increase of global temperatures within $1.5{ }^{\circ} \mathrm{C}$, about $90 \%$ of coal and $60 \%$ of oil and methane must remain unextracted. The study further adds that global oil and gas production must decline by $3 \%$ every year by 2050 . While more than 40 countries agreed to quit coal for power generation and 23 countries signed for 'COP26 Coal to Clean Power Transition Agreement' for the first time, some of the largest coal producers went missing from the agreement including Australia, China, India and United States (US). Hence, the final pact went from 'phasing out coal' to 'phasing down coal'. This is a major setback to the goals of COP26 and it is unlikely to limit global warming to the $1.5^{\circ} \mathrm{C}$ that is needed to avert disasters. With around $36 \%$ of the total human population residing in China and India (https://beef2live.com/story-world-population-ranki ng-countries-0-106889), these countries have their own worries to support their people, many of whom are in low income group. Hence, this requires prompt discussions and immediate action and support at international level.

Similarly, deforestation is among the major drivers of climate change and past forest protections acts and agreements have failed to mitigate the loss of forest cover (https://www.dw.com/en/zero-deforestation-commitmentempty-promises-or-a-workable-plan/a-59700862). Forests cover about $31 \%$ of global land and one-third of the area is of primary origin (https://www.fao.org/state-of-forests/ en/). Protecting forest loss and reversing unprecedented rate of deforestation is critical for climate change and biodiversity loss. Global Forest Watch report states that forests act as sinks and absorb a net of 7.6 billion metric tonnes $\mathrm{CO}_{2}$ per year, i.e. more than 1.5 times carbon emitted by US annually (https://www.globalforestwatch. org/blog/climate/forests-carbon-emissions-sink-flux/). Although more than 130 countries at COP26 have pledged to reverse deforestation by 2030 , some of them backed out during the final proposal despite having a large proportion of forest covers that need immediate conservation measures. Situation is already grave and past record reveals that we have lost huge chunks of forest areas. State of
World's Forest Report by Food and Agricultural Organization FAO (2020) suggests that since 1990, forest loss has been estimated to be 420 million hectare, mainly due to land conversion by humans. According to a data of World Resource Institute, about 12.2 million hectares of forest cover was lost in 2020 only. Of this area, around 4.2 million hectares (an area equal to the size of Netherlands) was lost in humid tropical primary forests, which are extremely important zones of carbon sequestration and biodiversity. The loss resulted in carbon emissions of 2.64 Gt which is equivalent to emissions of 570 million cars (https://research.wri.org/gfr/forest-pulse). Another report by World Wildlife Fund for Nature (WWF) suggests that in the last 50 years, we have lost approximately $17 \%$ of the Amazon rainforests mainly due to conversion of forest for cattle ranching. Other drivers include agriculture, poorly planned infrastructure and illegal logging (https://www. worldwildlife.org/threats/deforestation-and-forest-degra dation). In addition, forest fires are another major cause of forest loss. In this regard, a series of satellite images by Monitoring of the Andean Amazon Project (MAAP) estimate that around 2.2 million hectares of the Brazilian Amazon's rainforest was burned in 2020. In fact, the report also reveals that there is a strong link between deforestation and forest fires and all of the major fires of 2021 broke out on land deforested in 2020, which was mainly due to anthropogenic reasons (such as agribusiness and cattle pastures) (https://news.mongabay.com/2021/06/the-brazi lian-amazon-is-burning-again/). Land use change is one of the biggest issues which requires to be taken up seriously.

In the same context, methane, the second biggest contributor to global warming after $\mathrm{CO}_{2}$, got a lot of attention at COP26. Although, methane concentration in atmosphere is just 2 parts per millions (PPM) as compared to $\mathrm{CO}_{2}(412$ PPM), but it has capacity to trap heat 84 times more than $\mathrm{CO}_{2}$ thus making it a nuisance as far as global warming is concerned (https://www.downtoearth.org.in/news/climatechange/cop26-report-card-methane-s-role-in-global-warmi ng-in-sharp-focus-for-the-first-time-80176). This was the first time that an event was dedicated on methane as 'global methane pledge' proposed by US and EU, to reduce methane emissions by $30 \%$ from levels of 2020 by 2030 . The pledge was signed by 105 nations, but the top three methane producing countries (China, India and Russia) that are responsible for about $35 \%$ of methane in atmosphere did not sign it. (https://www.aljazeera.com/news/2021/11/14/infographicwhat-has-your-country-pledged-at-cop26). Agriculture, land use and forestry have intricate linkages with global warming and are responsible for around quarter of greenhouse gas emissions. There were expectations that COP26 would witness marked changes in food and agricultural system such as shifting towards sustainable consumption of meat and dairy, but that also showed no concrete achievements. 
Another goal was at protecting communities and natural habitats. This calls for conservation and restoration of ecosystems and also developing defences, warning systems and resilient infrastructure (https://ukpublichealthnetwork. org.uk/cop26-goal-two-adapt-to-protect-communities-andnatural-habitats/). It is high time to take into account the preservation of lands and livelihoods of indigenous people and forest communities as they are the ones who are least responsible for causing damage to the environment but most affected due to climate change and global warming. Natural disasters like storms, floods and wildfires are escalating at a sharp speed around the world, mainly due to increased anthropogenic activities. A report by WMO suggests that rapid pace of climate change has increased the frequency of natural disasters by five-fold in last 50 years, affecting poorer and developing countries in particular (https://news.un.org/ en/story/2021/09/1098662). The analysis is based on Centre for Research on the Epidemiology of Disasters' (CRED) Emergency Events Database (EM-DAT). The report reveals that between 1970 and 2019, 22,326 disasters were recorded, of which 11,072 were caused due to weather, climate and water hazards, resulting in 2.06 million deaths and US\$ 3.64 trillion of economic losses (Atlas Of Mortality And Economic Losses From Weather, Climate And Water Extremes (1970-2019) https://library.wmo.int/doc_num.php?expln um_id=10769). This calls for development of proactive measures and integrated policies to reduce disaster related risks to vulnerable communities.

Funding is an intrinsic part of climate change and billions of dollars need to be assembled and allocated for tackling the situation, including for research, innovation and implementation of green technologies. In this context, the goal focuses on mobilising finance, suggesting that the developed countries must ensure to keep their promise of organizing USD 100 billion for climate finance per year. In a report by UN (2020) it was stated that the financial counting for 2020 has fallen short and is far from the set target (https://www.un.org/sites/un2.un.org/files/100_billion_ climate_finance_report.pdf). An Organisation for Economic Co-operation and Development (OECD) report states that the developed countries are lagging behind by some 20 billion USD (https://www.oecd.org/env/cc/oecd-climate-finan ce-projection.htm). According to Adaptation Gap Report (2020) developing countries still need 70 billion per year to recover the costs for adaptation process and will require USD 140-300 billion by 2030 (https://www.nature.com/artic les/d41586-021-02846-3).

Last goal is to work together to deliver. This will require governments, public and private sector and financial institutions to collaborate at global level (https://www.petersonco ntrolunion.com/en/news-media/news/for-businesses-to-achie ve-net-zero-funding-for-environmentally-friendly-enter prises-must-be-forthcoming). The leading nations have been inconsistent in chasing to stabilize earth's climate. Every country needs to be decisive in their ambition to make it a reality rather than just making promises. Regarding this we have to go for "one nature one planet approach". An international watchdog such as a specific government or advocacy organization is now necessary so as to implement the policies related to climate change and environment. Time has come to work in unison to tackle the environmental issues and put aside the various divides which not only impact the human societies but also nature as a whole.

If aspirations of COP26 are to be met, we need to immediately take action to implement the targets both at micro and macro levels. It is also important to mention that progress towards combating climate change, which is the core of COP26 summit, is also a roadmap to Sustainable Development Goals 2030 (SDGs 2030). Therefore, any blowout to the aims of COPs also intersects with the SDGs (https:// www.the-ies.org/sites/default/files/documents/cop26_the_ sdgs.pdf). Climate resilient development demands an integrated approach for sustainability, economic growth and equitable human environment. To stabilize climate and move towards sustainability, climate smart agriculture, sustainable forest management, early warning and sharing systems, resilient infrastructure, soil and water conservation and diversification of livelihood must be adopted. Realising the importance of ocean's contribution towards climate change and scaling up of ocean-based strategies is also needed to accelerate net-zero carbon world as they are the natural sinks to $\mathrm{CO}_{2}$. Strict laws must be formulated to conserve natural resources and biodiversity. Remote sensing and geographical information system (GIS) can be helpful tools for monitoring and investigating any kind of over-exploitation (Arora and Mishra 2020). Moreover, it has become urgent to accelerate the efforts to phase-down coal power and stop fossil fuel subsidies without any further dilutions. Labelling of carbon footprint on packaged products must be done to increase the understanding of carbon emission and its control among the consumers. Gross Domestic Product (GDP) should be replaced with Gross Carbon Footprint (GCF) and Gross Sustainable Production (GSP) for assessment of sustainable development and measuring the impact of production on the environment (Arora and Mishra 2019). To increase awareness of the current climate crisis, educational and media programs should also be encouraged, especially the participation of young generation to make it a public movement. This will put pressure on policymakers to deliver a positive outcome. Hundreds of natives and local communities along with activists marching outside the Glasgow conference is already a proof that people are not ready to be in this existential crisis that demands losing their health, infrastructure, jobs and above all, their lives. Climate justice for poor, marginalised communities like those from vulnerable habitats and Small Island Developing States (SIDS), most vulnerable 
to climate change and unable to bear the hardships, food insecurity and displacements must be addressed at a very urgent basis. This is a matter of human rights and also right of living for every species on earth and hence unified laws and negotiations must be implemented. It is imperative that we as a society must urge and take a step in the direction of protecting those who are weakest and least responsible for any climate emergency by allotting monetary or other systems of help to them. Financial support from businesses, non-profit organizations, societies and developing nations could be vital in fulfilling this agenda. Also, developed countries must deliver on the USD 100 billion funding as early as possible, to give it a momentum. Moreover, restriction and sanctions should be levied on those that do not follow the guidelines. This kind of socio-economic justice will engage more people who were not earlier involved in this course and will make this climate emergency more relatable to these individuals. Nature-based solutions are integral and must be adapted at global, national and local levels. Ecosystem-based Adaptation (EbA), is one such solution and could be useful in meeting the challenges of climate change, which involves conservation, sustainable management and restoration of ecosystems. It will reduce climaterelated vulnerabilities and build resilience to human communities by harnessing ecosystem services and biodiversity conservation (https://www.iucn.org/resources/issues-briefs/ ecosystem-based-adaptation). It is also necessary to realise the importance of cumulative progress as each goal is interlinked with the other.

It has become crucial to make COP26 agendas a success story, which is currently lacking the required enthusiasm and lying in more of a dormant state. We are in the midst of a climate crisis that is linked to every realm of our life and civilization. The clock is ticking fast and this may be our last chance to keep global temperatures in check and prevent the impacts of catastrophic events due to climate change. We need to build tighter deadlines and resolutions to make up the outcomes of COP26. It is high time to give certainty to the approaches that have been promised in support of mitigation and adaptation strategies. This can be achieved only when every nation steps in and commitments towards environment and nature are fulfilled.

\section{References}

Arora NK, Mishra I (2019) United Nations Sustainable Development Goals 2030 and environmental sustainability: race against time. Environ Sustain 2:339-342. https://doi.org/10.1007/ s42398-019-00092-y

Arora NK, Mishra I (2020) Ocean sustainability: essential for blue planet. Environ Sustain 3:1-3. https://doi.org/10.1007/ s42398-020-00100-6

Welsby D, Price J, Pye S, Ekins P (2021) Unextractable fossil fuels in a $1.5^{\circ} \mathrm{C}$ world. Nature 597:230-234. https://doi.org/10.1038/ s41586-021-03821-8

Publisher's Note Springer Nature remains neutral with regard to jurisdictional claims in published maps and institutional affiliations. 